\title{
MEASUREMENT OF VALIDITY AND RELIABILITY OF CUSTOMER SATISFACTION QUESTIONER in E-BOARDING APPICATIONS
}

\author{
Sisilia Thya Safitri ${ }^{1}$ Dwi Mustika Kusumawardani ${ }^{2}$; Citra Wiguna ${ }^{3}$; Didi Supriyadi; Intan Yulita $^{5}$ \\ Information Systems S1 Study Program \\ Institut Teknologi Telkom Purwokerto, Indonesia \\ www.ittelkom-pwt.ac.id \\ 1sisil@ittelkom-pwt.ac.id; ${ }^{2}$ dwimustika@ittelkom-pwt.ac.id; ${ }^{3}$ citra@ittelkom-pwt.ac.id; \\ 4didisupriyadi@ittelkom-pwt.ac.id; 517103094@ittelkom-pwt.ac.id
}

\begin{abstract}
PT. Kereta Api Indonesia (Persero) is the largest company in Indonesia which is engaged in railroad transportation. One of the technological innovations carried out by PT KAI (Persero) is to make the KAI Access application with the latest feature is e-boarding. Through the e-boarding feature provided by PT KAI, KAI seeks to provide excellent service to customers. Not many customers use the e-boarding application as a gap between PT KAI's vision and train customers. The gap that exists between the vision and customer acceptance of information technology needs to be measured to determine the extent to which the implementation of the information technology is accepted by the customer. One method used to measure customer satisfaction is to use the use questionnaire. Before measuring customer satisfaction using the Use questionnaire, each item of questions must be tested for validity and reliability. The purpose of measuring the validity and reliability of this research is to ensure the accuracy and reliability of each question on the questionnaire as a test tool. The validity test results used by using the construct validity technique are valid. The reliability test results using the split-half reliability technique have a value of 0.9896 or equivalent to the very high-reliability criteria.
\end{abstract}

Keywords: E-Boarding, Customer Satisfaction, Validity, Reliability

Intisari-PT. Kereta Api Indonesia (Persero) merupakan sebuah perusahaan terbesar di Indonesia yang bergerak di bidang transportasi kereta api. Salah satu inovasi teknologi yang dilakukan oleh PT KAI (Persero) adalah membuat aplikasi KAI Access dengan fitur terbaru adalah $e$ boarding. Melalui fitur e-boarding yang disediakan oleh PT KAI, KAI berupaya memberikan pelayanan prima kepada customer. Belum banyak pelanggan yang menggunakan aplikasi e-boarding menjadi gap antara visi PT KAI dan pelanggan kereta api. Gap yang ada antara visi dan penerimaan pelanggan terhadap sebuah teknologi informasi perlu diukur untuk mengetahui sejauh mana implementasi teknologi informasi tersebut diterima oleh pelanggan. Salah satu metode yang digunakan untuk mengukur kepuasan pelanggan adalah dengan menggunakan use questionnaire. Sebelum dilakukan pengukuran kepuasan pelanggan dengan menggunakan Use questionnaire, maka setiap item pertanyaan harus dilakukan uji validitas dan reliabilitas. Tujuan pengukuran validitas dan reliabilitas pada penilitian ini adalah memastikan ketepatan dan kehandalan setiap pertanyaan pada kuesioner sebagai alat uji. Hasil uji validitas yang digunakan dengan menggunakan teknik validitas konstruk adalah bernilai valid. Hasil uji reliabilitas dengan menggunakan teknik split-half reliability memiliki nilai 0,9896 atau setara dengan kriteria reliabilitas sangat tinggi.

Kata Kunci: E-Boarding, Validitas, Kepuasan Pelanggan, Reliabilitas.

\section{INTRODUCTION}

In 2009 the directors of PT Kereta Api Indonesia (Persero) issued a notice containing a new vision for PT. Kereta Api Indonesia (KAI) Persero namely "Being the best railway service provider that focuses on customer service and meets the expectations of stakeholders". Through this vision, there are 5 organizational cultures promoted by PT KAI (Persero), namely Integrity, Professional, Safety, Innovation and Excellent Service (PT. Kereta Api Indonesia, 2019). PT Kereta Api Indonesia (Persero) as a provider of land transportation services continues to strive to provide excellent service to customers to achieve the company's competitive advantage. One of the efforts made by utilizing information technology to make easier for customers. One of the information technologies developed is a mobile-based application. 
The selection of mobile-based application development conducted by PT KAI is something that is appropriate and in accordance with the current condition of Indonesian society where as many as $93.9 \%$ use smartphones to connect to the internet. Figure 1 is the result of a survey conducted by the Indonesian Internet Service Users Association showing the percentage of the number of devices used by Indonesian internet users to connect to the internet

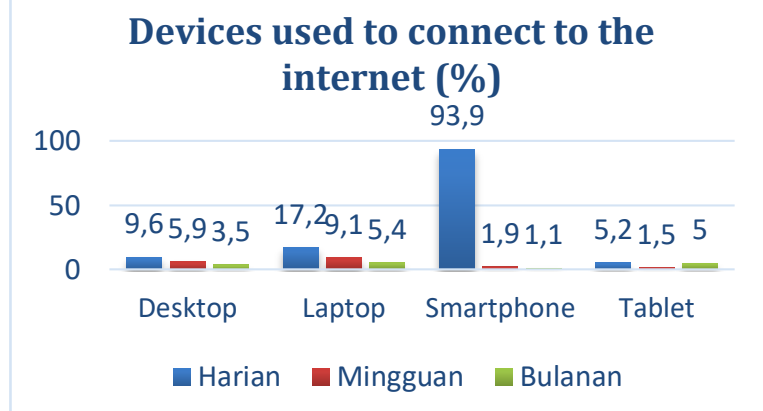

Source: (APJII, 2019)

Figure 1 Percentage of the number of devices used to connect to the internet

The KAI Access application as a mobile application was developed on July 15, 2014 by PT Kereta Api Indonesia (Persero). As a time goes by, PT KAI continues to be updated and added features to the KAI Access application. The features provided are ticket booking, ticket cancellation, ticket schedule changes, local train ticket purchase, train ticket purchase 1 hour before departure (or go show) and e-boarding pass. The e-boarding feature is a feature that can be used / will appear 2 hours before the Train's departure.

The advantage provided by the e-boarding feature for train passengers is that train passengers leaving will not need to queue to print boarding passes on the Check in counter machine. The check-in process can be carried out by showing e-boarding on the passenger cellphone. Specifically, the research to be carried out is on the e-boarding feature in the KAI Access application. Research focuses on the e-boarding feature based on observations that have been made there are still many passengers who do not use the e-boarding feature during the check-in process.

In accordance with the vision of PT KAI, the innovations provided by PT KAI are expected to meet customer needs. The e-boarding feature was created to reduce the queue of potential passengers at the Check in counter machine. But in reality, there are only a few passengers who use eboarding when checking in. The gap between the company's vision and customer response becomes a basis that needs to be explored to what extent applications developed by PT KAI (Persero) can meet stakeholder expectations. Rail passengers are the main stakeholders owned by PT KAI (Persero). Customer satisfaction is one method that can be used to measure customer satisfaction with a service.

Customer Satisfaction needs to be done to improve the performance of company management. Customer Satisfaction or in Indonesian known as customer satisfaction is something that is often associated with customer ratings of a product or service they use (Biesok \& Wyród-Wróbel, 2011) .

The method that can be used to measure customer satisfaction is to use the USE Questionnaire using a Likert rating scale. As a test material to measure customer satisfaction, the components of questions that have been compiled by questionnaire need to be tested for validity and reliability. Validity and reliability testing is a test conducted to the extent that the questionnaire as a measuring tool to be used can be trusted and the results are accountable (Deniz \& Alsaffar, 2013)

The measurement of the validity and reliability of the questionnaire was carried out with the aim that each question item on the questionnaire as a measure of customer satisfaction in the Indonesian Railroad e-boarding application is an appropriate and consistent measure if used repeatedly.

\section{MATERIAL AND METHOD}

The list of questions on the questionnaire to measure customer satisfaction refers to the use questionnaire method. After the questionnaire has been prepared, the validity and reliability test is carried out using a probability sampling multistage random sampling technique. Multistage random sampling techniques can be used for populations with large areas (Sedgwick, 2015). In this study, the population is divided into each of PT KAI's Operational Areas (DAOP) spread across Java. Samples were taken to do a trial "trial" in the field. This "trial" trial was carried out through an electronic questionnaire with a filling time span of September 1 - September 302019.

The validity value of a questionnaire will indicate precisely the measuring instrument used to measure. The questionnaire used as a data collection tool must be able to describe the research topic to be examined. One measure of the validity of a questionnaire is to use construct validity. Test criteria are performed by calculating the product moment correlation (r). The calculation formula $r$ can be seen in equation (1). After calculating the moment product correlation value, the test continues with the t-test. Criteria to determine the results of calculations can be done 
by comparing the value of t-count with the value of $t$ on the t-table. If t-count $\mathrm{t}$-table, it can be concluded that the item is valid (Widi, 2011). The calculation formula to get the t-value can be seen in equation (2).

$\mathrm{r}_{\mathrm{xy}}=\frac{n \sum X_{i} Y_{i}-\left(\sum X_{i}\right)\left(\sum Y_{i}\right)}{\sqrt{\left(n \sum X_{i}^{2}-\left(\sum X_{i}\right)^{2}\right)\left(n \sum Y_{i}^{2}-\left(\sum Y_{i}\right)^{2}\right)}}$

Note :

$r_{\mathrm{xy}}=$ Correlation coefficient

$\mathrm{n}=$ Number of respondents

$\mathrm{X}=$ Score of each item

$\mathrm{Y}=$ Scores of all respondent items

$t_{\text {hitung }}=\frac{r_{x y \sqrt{(n-2)}}}{\sqrt{\left(1-r_{x y}^{2}\right)}}$

Reliability testing needs to be done on the questionnaire instrument with the aim of being able to know the consistency of the questions used on the questionnaire instrument so that the questionnaire can be trusted (Triana \& Oktavianto, 2013). There are four methods to measure the reliability of a questionnaire, namely retestreliability, parallel-forms reliability, inter-rater reliability and split-half reliability (Mohajan, 2017). Reliability calculation techniques in this study are using split-half reliability techniques because the questions raised are even. The split-half reliability technique has a way of dividing the test into two equal parts, so that each test has two scores, namely the first score (initial / odd questions) and the second score (final / even questions). Each half of the questions is calculated the reliability coefficient with the formula:

$\mathrm{rij}=\frac{n \sum i j-\left(\sum i\right)\left(\sum j\right)}{\sqrt{\left(n \sum i^{2}-\left(\sum i\right)^{2}\right)\left(n \sum j^{2}-\left(\sum j\right)^{2}\right)}}$

Note:

$\mathrm{r}_{\mathrm{ij}}=$ reliability coefficient

$\mathrm{n}=$ number of respondents

$\mathrm{i}=$ calculation for odd questions

$\mathrm{j}=$ calculation for even questions

After calculating the reliability coefficient for each group of odd and even questions, the next step is to calculate the reliability using the Spearman Brown formula.

$\mathrm{rij}=\frac{2 * r_{i j}}{1+r_{i j}}$
After calculating the reliability value, then do the matching value in the reliability interpretation table.

\section{RESULTS AND DISCUSSIONS}

Based on the distribution of questionnaires that have been done, the respondents who filled out the questionnaire were 89 respondents. After conducting data checking, valid data that can be done the next processing stage is 80 respondent data. The distribution of respondents is as follows:

Table 1 Distribution of Respondent's Occupation

\begin{tabular}{lc}
\multicolumn{1}{c}{ Occupation } & Number \\
\hline Teaching Staff (Teacher / Lecturer / & 6 \\
Mentor) & 68 \\
\hline Student / Student & 4 \\
\hline Private employees & 1 \\
\hline Government employees & 1 \\
\hline Businessman
\end{tabular}

Source: (Safitri, 2019)

Table 2 Distribution of railroad usage within 1 month

\begin{tabular}{ll}
\multicolumn{1}{c}{$\begin{array}{c}\text { Railroad usage within } 1 \\
\text { month }\end{array}$} & Number \\
\hline$\leq 1$ times & 40 \\
\hline $2-5$ times & 32 \\
\hline $6-10$ times & 6 \\
\hline $11-15$ times & 1 \\
\hline$>15$ times & 1 \\
\hline
\end{tabular}

Source:(Safitri, 2019)

Questionnaire questions given refer to the question template using the questionnaire method. Use Questionnaire consists of four aspects of questions, namely usefulness, ease of use, ease of learning and satisfaction.

Detailed questions for each aspect of the questions on the customer satisfaction questionnaire used are as follows:

1. Usefulness

V1 = e-boarding can increase effectiveness at check-in

V2 = e-boarding helps me be more productive in checking in

$\mathrm{V} 3=$ e-boarding is easy to use

$\mathrm{V} 4=\mathrm{e}$-boarding is able to remind me of the time of departure

V5 = e-boarding is easier to use than paper boarding passes

V6 = e-boarding can save time when I leave

V7 = e-boarding according to my needs

V8 = e-boarding according to my expectations for 


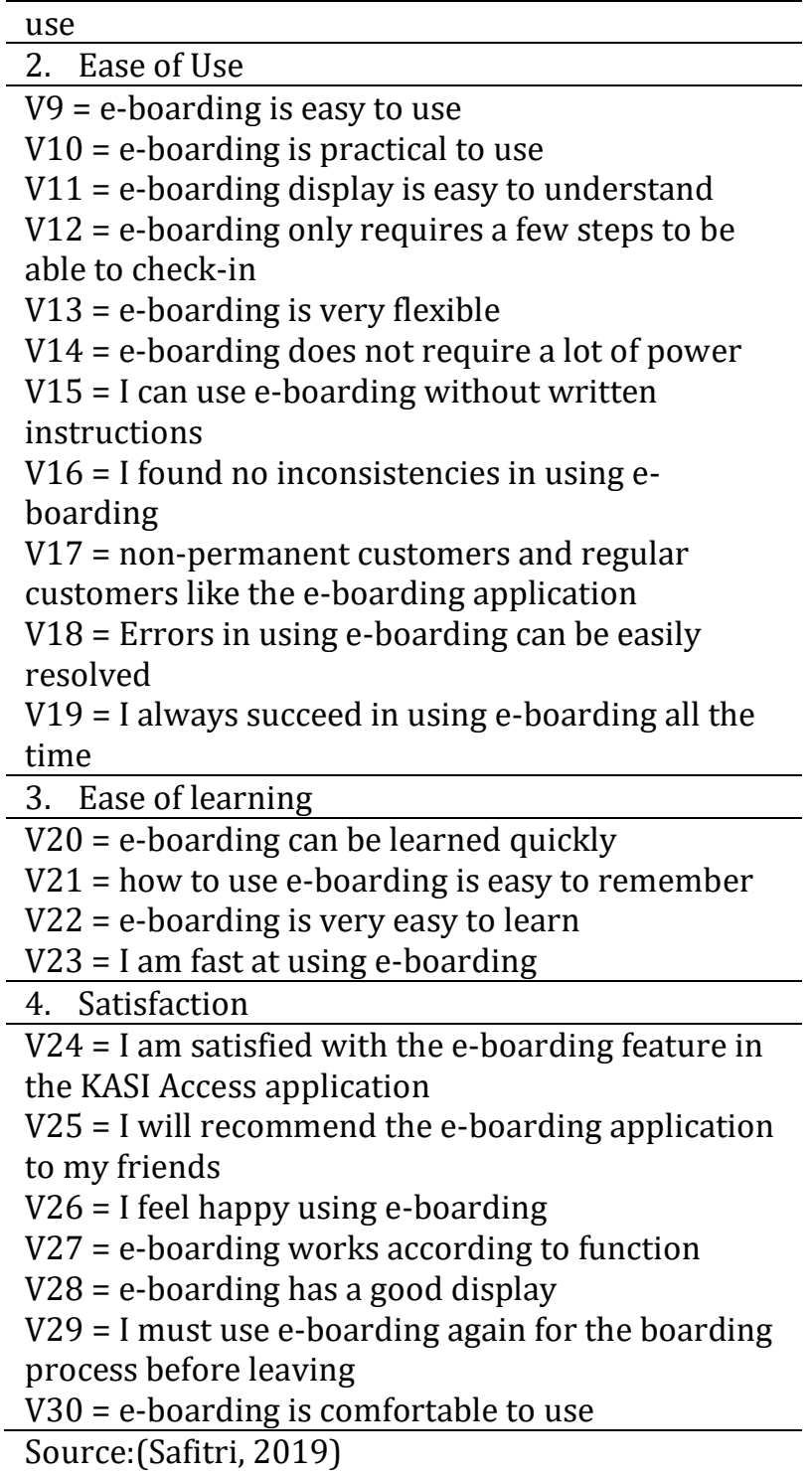

Table 3 The results of filling out the questionnaire by 80 respondents

\begin{tabular}{llllllll}
\hline & Q1 & Q2 & Q3 & Q4 & $\ldots$ & Q30 & $\begin{array}{l}\text { Number } \\
(\mathrm{y})\end{array}$ \\
\hline R1 & 5 & 5 & 5 & 3 & & 4 & 134 \\
\hline R2 & 5 & 5 & 5 & 5 & & 5 & 146 \\
\hline R3 & 4 & 4 & 5 & 3 & 3 & 117 \\
\hline R4 & 5 & 5 & 5 & 5 & & 5 & 148 \\
\hline. &. &. &. &. &. &. &. \\
. &. &. &. &. &. &. &. \\
. &. &. &. &. &. &. &. \\
. &. &. &. &. &. &. &. \\
\hline R80 & 4 & 4 & 4 & 4 & & 5 & 142 \\
\hline Total & 344 & 339 & 344 & 312 & 338 & 9892 \\
\hline Source & & & &
\end{tabular}

Source:(Safitri, 2019)

In accordance with the results presented in table 3, the next step is to determine the validity value for each question item. Based on the calculation formula (1), the validity calculation for item 1 is as follows: $r_{x y(1)}=$ coefficient of validity of questions 1

$\mathrm{N}=80$

$\sum_{x y 1}=44361$

$\sum_{x 1}=344$

$\sum_{y}=9892$

$\sum_{x^{2}}=1558$

$\sum_{y^{2}}=1274670$

$\mathrm{r}_{\mathrm{xy}(1)}=0,884$

The validation calculations for item 2 are as follows:

$r_{x y}(2)=$ coefficient of validity of questions 2

$\mathrm{N}=80$

$\sum_{x y 2}=43659$

$\sum_{x 1}=339$

$\sum_{y}=9892$

$\sum_{x^{2}}=1511$

$\sum_{y^{2}}=1274670$

$\mathrm{r}_{\mathrm{xy}(2)}=0,889$

Furthermore, this calculation is carried out until the last item. The validity calculation for the 30th question is as follows:

$r_{x y(30)}=$ coefficient of validity of questions 30

$\mathrm{N}=80$

$\sum_{x y 2}=43569$

$\sum_{x 1}=338$

$\sum_{y}=9892$

$\sum_{x^{2}}=1504$

$\sum_{y^{2}}=1274670$

$\mathrm{r}_{\mathrm{xy}(30)}=0,897$

After all $r$ values on each item have been calculated, do the calculations to find the $t$ value. The implementation to find the value of $t$ arithmetic for each problem is as follows:

$t_{(1)}=16,72$

$t_{(2)}=17,17$

The next step is to calculate the $t$ value for all questionnaire questions. The results of the calculation of the value of $t$ in the 30 th problem as the last question are as follows:

$t_{(30)}=17,94$

After calculating $\mathrm{t}$ for each question, a comparison is performed with the values in table t. The values taken in table $t$ are at the $95 \%$ confidence level and the degree of freedom (df) $=\mathrm{N}-2$. The number of respondents $(\mathrm{N})$ who filled in the data validly was 80 , so the degree of freedom obtained was 78

Based on the table, with $\mathrm{df}=78$ and $95 \%$ confidence level, the value of $t$ is 1.66462 . 
After calculating the value of $\mathrm{t}$ for all items, the next step is to compare the results of the calculation of the value of $t$ with the value in table $t$. Table 4 is the result of validity for each questionnaire question conducted. If the value of $t$ in each question is greater than the value of table, then it can be said that the question is valid.

Table 4 Results of questionnaire validity

\begin{tabular}{|c|c|c|c|}
\hline Items & Value $t$ & Value $t$ tabel & Result \\
\hline 1 & 16,72 & 1,66462 & Valid \\
\hline 2 & 17,17 & 1,66462 & Valid \\
\hline 3 & 18,56 & 1,66462 & Valid \\
\hline 4 & 8,16 & 1,66462 & Valid \\
\hline 5 & 12,64 & 1,66462 & Valid \\
\hline 6 & 15,75 & 1,66462 & Valid \\
\hline 7 & 14,57 & 1,66462 & Valid \\
\hline 8 & 17,12 & 1,66462 & Valid \\
\hline 9 & 17,10 & 1,66462 & Valid \\
\hline 10 & 14,66 & 1,66462 & Valid \\
\hline 11 & 15,94 & 1,66462 & Valid \\
\hline 12 & 11,89 & 1,66462 & Valid \\
\hline 13 & 16,84 & 1,66462 & Valid \\
\hline 14 & 14,61 & 1,66462 & Valid \\
\hline 15 & 10,99 & 1,66462 & Valid \\
\hline 16 & 11,41 & 1,66462 & Valid \\
\hline 17 & 11,13 & 1,66462 & Valid \\
\hline 18 & 7,45 & 1,66462 & Valid \\
\hline 19 & 13,88 & 1,66462 & Valid \\
\hline 20 & 17,91 & 1,66462 & Valid \\
\hline 21 & 15,53 & 1,66462 & Valid \\
\hline 22 & 18,27 & 1,66462 & Valid \\
\hline 23 & 15,04 & 1,66462 & Valid \\
\hline 24 & 18,86 & 1,66462 & Valid \\
\hline 25 & 15,78 & 1,66462 & Valid \\
\hline 26 & 17,72 & 1,66462 & Valid \\
\hline 27 & 17,42 & 1,66462 & Valid \\
\hline 28 & 10,05 & 1,66462 & Valid \\
\hline 29 & 11,08 & 1,66462 & Valid \\
\hline 30 & 17,94 & 1,66462 & Valid \\
\hline
\end{tabular}

After calculating the validity, each question needs to be measured reliability value on each question. In this study the method used to measure the reliability of the questionnaire is to use the Spearman Brown split half technique. The reliability testing steps for split half spearman brown are as follows:

1. Compile even and odd question questionnaire data

Table 5 List the value of odd questions

\begin{tabular}{llllllll}
\hline & Q1 & Q3 & Q5 & Q7 & $\ldots$ & Q29 & $\begin{array}{l}\text { Total } \\
\text { (i) }\end{array}$ \\
\hline R1 & 5 & 5 & 4 & 5 & & 5 & 68 \\
\hline R2 & 5 & 5 & 5 & 5 & & 5 & 74 \\
\hline R3 & 4 & 5 & 4 & 4 & & 1 & 58 \\
\hline
\end{tabular}

\begin{tabular}{|c|c|c|c|c|c|c|c|}
\hline & Q1 & Q3 & Q5 & Q7 & $\ldots$ & Q29 & $\begin{array}{l}\text { Total } \\
\text { (i) }\end{array}$ \\
\hline $\mathrm{R} 4$ & 5 & 5 & 5 & 5 & & 5 & 74 \\
\hline . & . & . & . & . & & . & . \\
\hline$\cdot$ & . & $\cdot$ & $\cdot$ & . & & . & . \\
\hline${ }^{\circ}$ & . & . & . & . & & . & . \\
\hline 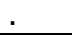 & . & . & . & . & & . & . \\
\hline R80 & 4 & 4 & 4 & 4 & & 5 & 71 \\
\hline
\end{tabular}

Table 5 List the value of even questions

\begin{tabular}{llllllll}
\hline & Q2 & Q4 & Q6 & Q8 & $\ldots$ & Q30 & $\begin{array}{l}\text { Total } \\
\text { j) }\end{array}$ \\
\hline R1 & 5 & 3 & 5 & 4 & 4 & 66 \\
\hline R2 & 5 & 5 & 5 & 5 & 5 & 72 \\
\hline R3 & 4 & 3 & 4 & 3 & 3 & 59 \\
\hline R4 & 5 & 5 & 5 & 5 & 5 & 74 \\
\hline$\cdot$ &. &. &. &. &. & $\cdot$ \\
. &. &. &. &. &. &. \\
. &. &. &. &. &. &. \\
. &. &. &. &. &. &. \\
\hline R80 & 4 & 4 & 4 & 4 & 5 & 71 \\
\hline
\end{tabular}

Table 7 Total scores for each odd and even questions

\begin{tabular}{|c|c|c|c|c|c|}
\hline & $\sum i$ & $\sum j$ & $\sum i^{2}$ & $\sum j^{2}$ & $\mathrm{i}^{*} \mathrm{j}$ \\
\hline R1 & 68 & 66 & 4624 & 4356 & 4488 \\
\hline $\mathrm{R} 2$ & 74 & 72 & 5476 & 5184 & 5328 \\
\hline R3 & 58 & 59 & 3364 & 3481 & 3422 \\
\hline $\mathrm{R} 4$ & 74 & 74 & 5476 & 5476 & 5476 \\
\hline . & . & 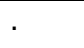 & $\cdot$ & $\cdot$ & ${ }^{\circ}$ \\
\hline . & . & . & . & . & . \\
\hline . & . & . & . & . & . \\
\hline . &. & . & . & . & . \\
\hline R80 & 71 & 71 & 5041 & 5041 & 5041 \\
\hline Total & 4977 & 4915 & 322963 & 314665 & 318521 \\
\hline
\end{tabular}

Source:(Safitri, 2019)

3. Calculate the correlation between scores of odd and even question questions (according to formula number 3)

$\mathrm{r}_{\mathrm{ij}}=0,9796$

4. Calculate reliability using the Spearman Brown formula (according to formula 4)

$r=0,9896$

Based on table 8 interpretation of reliability, the final value of reliability to measure the level of customer satisfaction in the e-boarding application of PT. KAI is very high. 
Table 8 Interpretation of reliability

\begin{tabular}{cc}
\hline Correlation Coefficient & Reliability criteria \\
\hline $0,81<\mathrm{r} \leq 1,00$ & Very High \\
\hline $0,61<\mathrm{r} \leq 0,80$ & High \\
\hline $0,41<\mathrm{r} \leq 0,60$ & Enough \\
\hline $0,21<\mathrm{r} \leq 0,40$ & Low \\
\hline $0,00<\mathrm{r} \leq 0,21$ & Very Low \\
\hline
\end{tabular}

Source :(Arikunto, 2010)

\section{CONCLUSION}

Questionnaire arrangement using the use questionnaire was carried out to measure customer satisfaction with e-boarding in the KAIAccess application. Validity measurement needs to be done on a measurement instrument that has the objective to measure the accuracy of the questionnaire as a measurement tool. The reliability of the questionnaire instrument was carried out to monitor the consistency of the questions raised on the questionnaire instrument. Using probability sampling - multistage random sampling technique, the number of questionnaire filler data to measure the validity and reliability values is 80 respondents from all DAOP PT KAI. Calculation of the validity value by using construct validity for the PT Kereta Api (Persero) e-boarding customer satisfaction questionnaire is valid. In the reliability calculation, the technique used is splithalf reliability with a reliability value of 0.9896 or has very high reliability criteria. Based on the results of the calculation of validity and reliability that have been done, the questionnaire as a measurement tool for assessing customer satisfaction on e-boarding PT Kereta Api Indonesia (Persero) has a valid value and has a very high reliability so that it can be used as a tool to measure customer satisfaction on the e- boarding on KAI Access at PT Kereta Api Indonesia (Persero). Suggestions that can be done for further research is to calculate the reliability of each aspect contained in the use questionnaire.

\section{REFERENCES}

APJII. (2019). Penetrasi \& Profil Perilaku Pengguna Internet Indonesia Tahun 2018. Apjii, 51.

Arikunto, P. D. S. (2010). Prosedur Penelitian: Suatu Pendekatan Praktik. Rineka Cipta.

Biesok, G., \& Wyród-Wróbel, J. (2011). Customer satisfaction - Meaning and methods of measuring. Marketing and Logistic Problems in the Management of Organization, (June), 23-41.

Deniz, M. S., \& Alsaffar, A. A. (2013). Assessing the validity and reliability of a questionnaire on dietary fibre-related knowledge in a Turkish student population. Journal of Health, Population and Nutrition, 31(4), 497-503. https://doi.org/10.3329/jhpn.v31i4.20048

Mohajan, H. K. (2017). Two Criteria for Good Measurements in Research: Validity and Reliability. Annals of Spiru Haret University. Economic Series, 17(4), 59-82. https://doi.org/10.26458/1746

PT. Kereta Api Indonesia. (2019). Company Profile PT. Kereta Api Indonesia 2019. Bandung.

Safitri, S. T. (2019). Customer Satisfaction pada fitur e-boarding di aplikasi kereta api Indonesia (KAI). Purwokerto.

Sedgwick, P. (2015). Multistage Sampling. BMJ (Online), https://doi.org/10.1136/bmj.h4155

Triana, D., \& Oktavianto, W. O. (2013). Relevansi Kualifikasi Kontraktor Bidang Teknik Sipil Terhadap Kualitas Pekerjaan Proyek Konstruksi Di Provinsi Banten. Jurnal Fondasi, 2(2), 182-190. 